\title{
ANALISA KREDIT MACET PROGRAM USAHA EKONOMI DESA SIMPAN PINJAM (UED SP) DALAM PERSPEKTIF EKONOMI ISLAM
}

\author{
Saifullah $^{1}$, Risman Hambali ${ }^{2}$, Nurul Huda ${ }^{3}$, Ririn Wise Liner ${ }^{4}$ \& Putri Nuraini ${ }^{5}$ \\ 1,2,3\&4 Jurusan Syariah dan Ekonomi Islam, Sekolah Tinggi Agama Islam Negeri Bengkalis \\ ${ }^{5}$ Fakultas Agama Islam, Universitas Islam Riau \\ Email : saifullahnurbi@gmail.com, rismanhambaliselari@gmail.com, hudaleres@gmail.com, \\ ririnliner@gmail.com, putrinuraini@fis.uir.ac.id
}

\begin{abstract}
ABSTRAK
Tujuan yang ingin dicapai dalam penelitian ini adalah untuk mengidentifikasi dan menganalisa penyebab terjadinya kredit macet UED SP Desa Lubuk Muda dalam perspektif ekonomi Islam. Indikator yang digunakan peneliti untuk mengidentifikasi dan menganalisa penyebab terjadinya kredit macet adalah; kelemahan dalam analisis kredit, kelemahan dalam dokumen kredit, kelemahan dalam supervisi kredit, kelemahan kebijakan kredit, Kecerobohan petugas, kelemahan dalam bidang agunan, kelemahan sumberdaya manusia, kelemahan teknologi, dan kecurangan petugas. Penelitian ini menggunakan metode kualitatif dengan teknik sampel purposive. Hasil penelitian ini membuktikan bahwa penyebab terjadinya kredit macet pada UED SP Desa Lubuk Muda adalah karena kelalaian petugas, sistem pengendalian/kontrol yang lemah serta kesadaran pemanfaat dalam membayar sejumlah hutangnya yang masih rendah.
\end{abstract}

Kata Kunci : Kredit Macet, UED SP, Ekonomi Islam.

\begin{abstract}
The aim of this research is to identify and analyze the causes of bad credit at UED SP in Lubuk Muda Village from an Islamic economic perspective. The indicators used by researchers to identify and analyze the causes of bad credit are; weakness in credit analysis, weakness in credit documents, weakness in credit supervision, weakness in credit policy, carelessness of officers, weakness in collateral, weakness in human resources, weakness in technology, and fraud of officers. This study used a qualitative method with a purposive sampling technique. The results of this study prove that the causes of bad credit at UED SP in Lubuk Muda Village are due to negligence of officers, weak control / control systems and awareness of users in paying a low amount of debt.
\end{abstract}

Keyword : Bad Credit/Jammed Credit, UED SP, Islamic Economic. 


\section{PENDAHULUAN}

Ekonomi Desa Simpan Pinjam (UED-SP) adalah suatu lembaga yang bergerak di bidang simpan pinjam dan merupakan milik masyarakat desa/kelurahan yang diusahakan serta dikelola oleh masyarakat desa/kelurahan. UED SP dibentuk melalui musyawarah desa/kelurahan dan ditetapkan dengan keputusan desa/kelurahan.

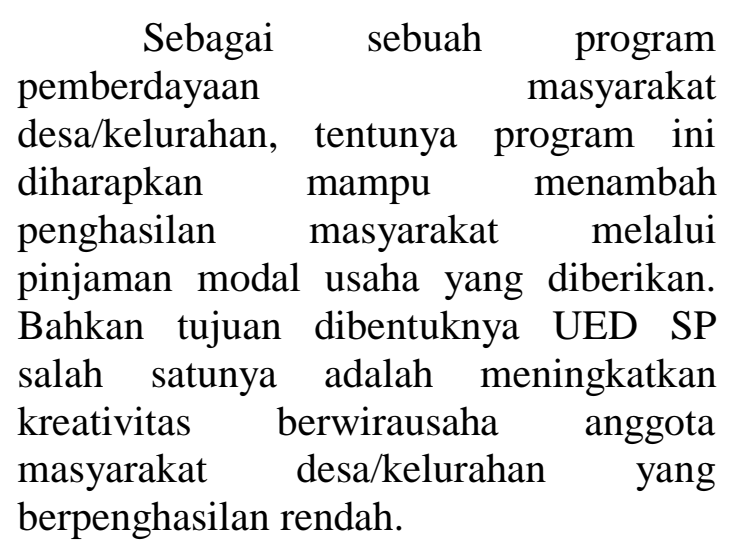

Islam sebagai risalah samawi yang universal, datang untuk menangani kehidupan manusia dalam berbagai aspek. Baik dalam aspek spiritual maupun aspek material. Artinya Islam tidak hanya aqidah, tetapi juga mencakup sistem politik, sosial, budaya dan perekonomian yang ditujukan untuk seluruh manusia. Inilah yang diungkapkan dengan istilah Ad Din yang mencakup masalah aqidah dan syariah. (Munawwir, 1997) Sebagai agama yang sempurna, Islam dilengkapi dengan sistem dan konsep ekonomi. Sistem ini dapat dipakai sebagai panduan bagi manusia dalam melakukan kegiatan ekonomi.

Masalah ekonomi yang dihadapi masyarakat secara prinsip berbeda-beda, baik sebab-sebab timbulnya masalah ekonomi yang berakibat metode merumuskan keputusannya pun berbeda. Keputusan ini akan menentukan araharah kebijakan ekonomi, namun penyebabnya sering kali timbul secara dominan adalah faktor kebijakan (policy) ekonomi yang menjadi penyebab timbulnya masalah ekonomi (Nuraini, 2019)

Di dalam Islam, istilah kredit sama dengan pembiayaan. Pembiayaan syariah/Islam merupakan sub sistem dari ekonomi Islam yang bersumber dari AlQur'an dan Hadis Nabi Besar Muhammad SAW. Al-Qur'an merupakan wahyu dari Allah SWT yang diperjelas melalui Sunnah termasuk Hadis Nabi SAW.

Dengan demikian, secara epistemologi ekonomi dan pembiayaan Islam berasal dari kedua sumber utama tersebut. Al-Qur'an berisikan ketentuan dan petunjuk bagi manusia dalam hubungan vertikal dengan Allah SWT atau beribadah dan juga mengatur hubungan yang bersifat horizontal antar sesama manusia atau bermuamalah. Oleh karena itu, ekonomi Islam bersandar pada prinsip tauhid atau Keesaan Tuhan.

Desa Lubuk Muda merupakan salah satu desa sekaligus menjadi Kecamatan Siak Kecil Kabupaten Bengkalis Provinsi Riau. (Huda, 2020) Desa Lubuk Muda melaksanakan program UED SP sejak tahun 2011 hingga saat ini. Sejumlah dana telah dicairkan kepada masyarakat dari UED SP Desa Lubuk Muda. Dari sekian banyak dana yang telah dicairkan tersebut, terdapat sejumlah tunggakan/kredit macet yang sangat tinggi sehingga mengakibatkan terganggunya pelaksanaan program tersebut.

\section{TINJAUAN PUSTAKA}

\section{Pinjaman}

Pinjaman adalah pemberian harta kepada orang lain yang dapat ditagih atau dimintai atau dengan kata lain meminjamkan tanpa mengharapkan imbalan. Dan suatu pinjaman juga adalah apa yang dimiliki satu orang lalu 
diberikan kepada yang lain kemudian dikembalikan dalam kepunyaannya dalam baik hati. (Antonio, 2001)

Pinjaman ('ariyah) berasal dari kata at-Ta'wur yaitu ganti mengganti pemanfaatan sesuatu kepada orang lain. Adapun 'ariyah secara terminologis berarti pembolehan pemanfaatan suatu barang (oleh pemilik kepada orang lain) dengan tetap menjaga keutuhan barang itu.

Dasar hukum pinjaman di dalam dalam Al-Qur'an dan terjemahan, (2017) adalah:

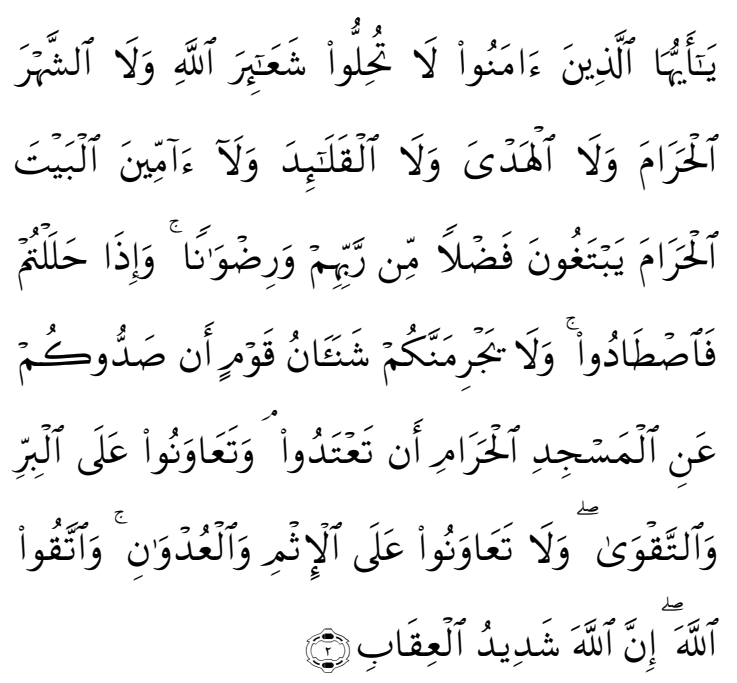

Artinya: Hai orang-orang yang beriman, janganlah kamu melanggar syi'ar-syi'ar Allah, dan jangan melanggar kehormatan bulan-bulan haram, jangan (mengganggu) binatang-binatang had$y a$, dan binatang-binatang qalaa-id, dan jangan (pula) mengganggu orang-orang yang mengunjungi Baitullah sedang mereka mencari kurnia dan keredhaan dari Tuhannya dan apabila kamu telah menyelesaikan ibadah haji, Maka bolehlah berburu. dan janganlah sekalikali kebencian(mu) kepada sesuatu kaum karena mereka menghalang-halangi kamu dari Masjidilharam, mendorongmu berbuat aniaya (kepada mereka). dan tolong-menolonglah kamu dalam (mengerjakan) kebajikan dan takwa, dan jangan tolong-menolong dalam berbuat dosa dan pelanggaran. dan bertakwalah kamu kepada Allah, Sesungguhnya Allah amat berat siksa-Nya. (QS. Al Maidah ayat 2)

\section{Pengertian Kredit}

Kata "kredit" berasal dari bahasa latin "credo" yang berarti "saya percaya", yang merupakan kombinasi dari bahasa sansakerta "cred" yang artinya "kepercayaan", dan bahasa latin "do" yang artinya "saya tempatkan" (Hariyani, 2013)

Kredit adalah penyediaan uang atau tagihan yang dapat dipersamakan dengan itu, berdasarkan persetujuan atau kesepakatan pinjam meminjam antara bank dengan pihak lain yang mewajibkan pihak peminjam untuk melunasi utangnya setelah jangka waktu tertentu dengan pemberian bunga.

\section{Faktor Penyebab Pembiayaan Bermasalah}

Dalam prakteknya (Kasmir, 2007) kemacetan suatu kredit disebabkan oleh dua unsur sebagai berikut:

1. Dari pihak perbankan/pemilik dana

Artinya pihak anilisis kurang teliti, sehingga apa yang seharusnya terjadi tidak diprediksi sebelumnya atau mungkin salah dalam melakukan perhitungan. Dapat pula terjadi kolusi dari pihak analisis kredit dengan pihak debitur sehingga dalam analisisnya dilakukan secara subjektif.

2. Dari pihak nasabah/masyarakat

Dapat dilakukan akibat dua hal, yaitu:

a) Adanya unsur kesengajaan. Nasabah/masyarakat sengaja tidak membayar kewajibannya kepada bank/lembaga keuangan non bank sehingga kredit yang diberikan macet. 
b) Adanya unsur ketidaksengajaan. Nasabah/masyarakat mau membayar tapi tidak mampu. Bisa jadi karena musibah seperti kabakaran, hama, kebanjiran dan sebagainya.

Menurut Mahmoedin, (2002) terdapat banyak faktor penyebab terjadinya kredit bermasalah, yaitu:

a. Faktor internal

1) Kelemahan dalam analisis kredit. Setiap analisis harus berdasarkan data yang benar-benar akurat, agar hasil analisis menjadi tepat.

2) Kelemahan dalam dokumen kredit. Salah satu kekuatan bank dalam menghadapi kenakalan nasabahnya, adalah kekuatan dan kelengkapan dokumen yang biasa digunakan sebagai senjata bank.

3) Kelemahan dalam supervisi kredit. Setiap usaha tentu ada resiko bisnis dan resiko non bisnis. Karena itu bank harus tahu persis setiap perkembangan usaha nasabahnya. Satu-satunya cara adalah dengan melakukan pengawasan dan pemantauan baik secara periodik maupun insidentil dan secara kontinyu agar setiap masalah dapat ditanggulangi secara disi.

4) Kelemahan kebijakan kredit. Setiap bank mempunyai kebijakan kredit yang sudah digariskan terlebih dahulu. Seperti masalah sistem, prosedur dan wewenang yang diberikan kepada pejabat bank. Kebijakan kredit ini bisa saja mengandung kelemahan yang mengakibatkan pelaksanaan juga menimbulkan kelemahan.

5) Kelemahan bidang agunan. Mungkin secara hukum setiap agunan telah diikat dengan baik dan kuat. Namun harus diingat bahwa barang jaminan tersebut secara fisik ada yang mudah berpindah tangan atau rawan kerusakan. Sehingga petugas pemeriksaan hendaknya melakukan pemantauan dengan pengawasan secara rutin dan insidentil terhadap barang jaminan.

6) Kesalahan sumber daya manusia. Sebagaimana tenaga untuk kredit recovery maka penyelamatan dan penyelesaian bukanlah pekerjaan yang mudah seperti melakukan analisis kredit biasa, diperlukan tenaga ahli dibiang penyelamatan dan penyelesaian kredit.

7) Kelemahan teknologi. Ketidakmampuan bank secara teknis dapat dalam berbagai bentuk antara lain keterbatasan peralatan, keterbatasan tenaga secara kuantitatif, keterbatasan kemampuan petugas secara kualitatif serta terbatasnya sarana dan prasarana yang berkaitan dengan pekerjaan teknis seperti komputer dan software.

Tujuh faktor tersebut peneliti jadikan sebagai indikator di dalam penelitian ini. Sehingga dengan melakukan pungujian terhadap indikator tersebut mampu menemukan masalah dan mencapai hasil penelitian yang baik.

b. Faktor internal nasabah

Faktor internal yang menyebabkan kredit bermasalah antara lain:

1) Kelemahan karakter nasabah.

2) Kelemahan kemampuan nasabah.

3) Musibah yang dialami nasabah.

4) Kecerobohan nasabah.

5) Kelemahan manajemen nasabah.

c. Faktor eksternal

Faktor eksternal adalah faktorfaktor yang berada diluar kekuasaan manajemen, seperti: 
1) Situasi ekonomi yang negatif dalam negeri yang merugikan.

2) Situasi politik dalam negeri yang merugikan.

3) Politik Negara lain yang merigikan.

4) Situasi alam yang merugikan.

5) Peraturan pemerintah yang merugikan.

Tujuan dan Kegiatan UED-SP (Usaha Ekonomi Desa Simpan Pinjam) Tujuan dibentuknya UED-SP adalah untuk:

1. Mendorong kegiatan perekonomian masyarakat Desa/Kelurahan.

2. Meningkatkan

kreativitas berwirausaha anggota masyarakat Desa/Kelurahan yang berpenghasilan rendah.

3. Mendorong usaha sektor informal untuk penerapan tenaga kerja bagi masyarakat Desa/Kelurahan.

4. Menghindari anggota masyarakat Desa/Kelurahan dari pengaruh pelepas uang dengan bunga tinggi yang merugikan masyarakat.

5. Meningkatkan peranan masyarakat Desa/Kelurahan dalam rangka menampung dan mengelola bantuan modal yang berasal dari Pemerintah dan atau sumber-sumber lain yang sah.

6. Memelihara dan meningkatkan adat kebiasaan gotong royong untuk gemar menabung secara tertib, teratur bermanfaat dan berkelanjutan.

\section{Teknik Penyelamatan Kredit Macet}

\section{Rescheduling}

a. Memperpanjang jangka waktu kredit.

b. Memperpanjang jangka waktu angsuran.

\section{Reconditioning}

Dengan cara menrubah persyaratan yang ada.

\section{Restructuring}

Tindakan kepada nasabah dengan cara menambah modal nasabah dengan pertimbangan nasabah memang membutuhkan tambahan dana dan usaha yang dibiayai memang masih layak. Tindakan ini dengan menambah kredit, dengan menambah equity.

\section{Kombinasi}

Merupakan kombinasi dari ketiga jenis di atas.

5. Penyitaan jaminan

Merupakan jalan terakhir apabila nasabah/masyarakat memang sudah benar-benar tidak punya etikad baik ataupun sudah tidak mampu lagi untuk membayar semua hutang-hutangnya. (Kasmir, 2008)

\section{Kredit Macet dalam Islam}

Di dalam kitab-kitab fikih dijelaskan bahwa suatu transaksi akan sah secara syariat Islam jika terbebas dari empat unsur utama, yaitu:

1. Riba (bertambah, bertumbuh, berkembang)

2. Zhalim (menganiaya/menyakiti orang lain)

3. Gharar (ketidakjelasan)

4. Maysir (judi)

\section{Pemberdayaan Ekonomi Masyarakat Muslim}

Pemberdayaan (empowerment), terkait dengan pengertian power, yaitu kekuatan atau keberdayaan. Power dapat diartikan sebagai kekuasaan atau powerover, yaitu dominasi yang didasarkan atas sanksi, ancaman, dan kekerasan. Dalam istilah empowerment, power diartikan sebagai: 
1. Daya untuk berbuat (power to),

Power to adalah kekuatan yang kreatif, yang membuat seseorang mampu melakukan sesuatu. Ini merupakan aspek individual dari pemberdayaan yaitu membentuk orang agar ia memiliki kemampuan untuk mengambil keputusan, memecahkan masalah, bekerja dan membangun berbagai keterampilan.

2. Kekuatan bersama (power with),

$$
\text { Power with, yaitu agar }
$$
membangun solidaritas atas dasar komitmen pada tujuan dan pengertian yang sama untuk memecahkan permasalahan yang dihadapi guna menciptakan kesejahteraan bersama.

\section{Kekuatan dari (power within).}

Power within membuat manusia lebih manusiawi karena di situ dibangun harga diri manusia dan penghargaan terhadap martabat manusia dan nilai-nilai yang mengalir dari martabat itu.

Pemberdayaan adalah upaya untuk membangun daya (masyarakat) dengan mendorong, memotivasi, dan membangkitkan kesadaran akan potensi yang dimilikinya serta berupaya untuk mengembangkannya. (Budisusila, 2009)

Keberdayaan masyarakat adalah unsur dasar yang memungkinkan suatu masyarakat bertahan, dan dalam pengertian yang dinamis mengembangkan diri dan mencapai kemajuan. Keberdayaan masyarakat menjadi sumber dari apa yang dikenal sebagai Ketahanan Nasional. Memberdayakan masyarakat berarti upaya untuk meningkatkan harkat dan mertabat lapisan masyarakat yang dalam kondisi tidak mampu melepaskan diri dari perangkap kemiskinan dan keterbelakangan. (Budisusila, 2009)

Hambatan besar dalam upaya pemberdayaan masyarakat miskin dirumuskan oleh Ginandjar dalam bentuk bias-bias, yaitu penggunaan paradigma (cara pandang) yang keliru tentang karakteristikn penduduk miskin, motivasi mereka, lembaga-lembaga yang dibentuk dan mengatur kehidupan mereka, dan perilaku ekonomi dan sosial-budaya yang diterapkannya. (Budisusila, 2009) Biasbias ini atau anggapan salah yang dimaksud adalah:

1. Dimensi rasional pembangunan lebih penting ketimbang dimensi moral;

2. Pendekatan pembangunan dari atas lebih unggul ketimbang pengalaman dan aspirasi dari bawah;

3. Bantuan materiil lebih diperlukan ketimbang ketrampilan teknis dan manajerial;

4. Teknologi dari luar lebih ampuh ketimbang teknologi yang sudah dikenal setempat;

5. Lembaga-lembaga yang dikembangkan rakyat setempat tidak efisien dan efektif;

6. Masyarakat tidak tahu apa yang diperlukan dan bagaimana memperbaiki nasibnya;

7. Orang miskin menjadi miskin karena bodoh dan malas;

8. Setiap investasi harus cepat menghasilkan;

9. Pertanian sebagai sektor tradisional tidak produktif dan tidak menguntungkan;

10. Akses masyarakat desa terhadap sumber dana sangat terbatas dan tidak dikembangkan karena dianggap beresiko tinggi.

\section{METODE PENELITIAN}

Metode penelitian yang dilakukan adalah penelitian deskriptif dengan pendekatan kualitatif. Firdaus dan Huda. (2020) penelitian kualitatif yaitu penelitian yang bermaksud untuk 
memahami fenomena tentang apa yang dialami oleh subjek penelitian, misalnya: perilaku, persepsi, motivasi, tindakan dan lain-lain secara holistik dan dengan cara deskripsi dalam bentuk kata-kata dan bahasa, pada suatu konteks khusus yang alamiah dan dengan memanfaatkan berbagai metode ilmiah. (Lexy, 2012)

Ciri khas penelitian kualitatif tidak dapat dipisahkan dari pengamatan berperan serta, namun peranan penelitilah yang menentukan keseluruhan skenarionya. (Lexy, 2012) Oleh sebab itu, yang menjadi instrumen yang digunakan pada penelitian ini adalah:

1. Wawancara (interview).

Wawancara merupakan salah satu teknik yang dapat digunakan untuk mengumpulkan data penelitian. Maka wawancara di dalam penelitian ini dilakukan kepada Ketua UED SP Periode 2014-2018, pemerintah Desa Lubuk Muda dan perwakilan BPD yang dianggap mampu menyalurkan aspirasi masyarakat.

\section{Observasi.}

Salah satu teknik yang dapat digunakan untuk mengetahui atau menyelidiki tingkah laku non verbal yakni dengan menggunakan teknik observasi. Maka observasi yang penulis lakukan di dalam penelitian ini adalah menganalisa secara langsung kondisi kredit UED SP Desa Lubuk Muda yang menjadi sampel di dalam penelitian ini.

\section{Dokumentasi.}

Dokumen merupakan catatan atau karya seseorang tentang sesuatu yang sudah berlalu. Dokumen tentang orang atau sekelompok orang, peristiwa atau kejadian dalam situasi sosial yang sesuai dan terkait dengan fokus penelitian adalah sumber informasi yang sangat berguna dalam penelitian kualitatif. Dokumen yang dibutuhkan dalam penelitian ini adalah data kredit macet UED SP Desa Lubuk Muda.

Menurut Bogdan dan Biklen, (1997) mengatakan analisis data kualitatif adalah upaya yang dilakukan dengan jalan bekerja dengan data, mengorganisasikan data, memilahmilahnya menjadi satuan yang dapat dikelola, mensintesiskannya, mencari dan menemukan pola, menemukan apa yang penting dan apa yang dipelajari dan memutuskan apa yang dapat diceritakan kepada orang lain. ( Lexy, 2012)

Maka, di dalam penelitian ini penulis menggunakan teknik analisa data dengan cara:

\section{Mengorganisir Data}

Peneliti berusaha mendapatkan data langsung dari subjek melalui wawancara terstruktur (untuk stakeholder pengurus UED SP Desa Lubuk Muda) kemudian dijadikan dalam bentuk tertulis dan dibaca berulang-ulang. Data dari wawancara ditranskripkan dan disusun secara sistematis. Sementara data dari analisis dokumen dan catatan perusahaan diorganisir ke dalam format yang sama dengan hasil wawancara.

\section{Data Reduction}

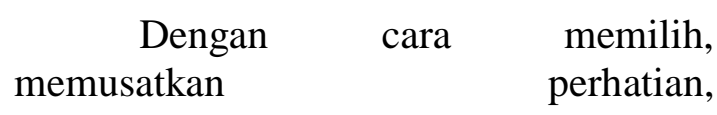
menyederhanakan, mengabstraksikan serta mentransformasikan data yang muncul dari catatan-catatan lapangan. (Sugiyono, 2018)

Langkah-langkah pokok yang dilakukan dalam penelitian ini adalah:

1. Membaca dan menganalisis kredit macet UED SP Desa Lubuk Muda tahun 2014-2018.

2. Menganalisis respon stakeholders terhadap kredit macet UED SP Desa Lubuk Muda. 
3. Berupaya memaparkan pembiayaan dalam perspektif ekonomi Islam.

\section{HASIL DAN PEMBAHASAN}

1. Kelemahan dalam analisis kredit

Berdasarkan wawancara peneliti bersama pengelola UED SP bahwa mekanisme pengajuan pinjaman yang dilakukan oleh pemanfaat kepada pengurus sudah sesuai dengan ketentuan yang berlaku. Namun diakui bahwa kemampuan di dalam menganalisa kredit oleh pengurus masih minim. Hal ini disebabkan selain pengurus tidak memiliki basis keilmuan dalam analisa kredit, pelatihan-pelatihan dan seminar tentang analisa kredit sangat jarang dilakukan. Oleh sebab itu kelemahan dalam analisa kredit sangat memungkinkan.

Di dalam Islam diajarkan bahwa setiap Muslim harus senantiasa memperbaiki kualitas diri dan bahkan menuntut ilmu di dalam Islam diwajibkan. Sebagaimana firman Allah SWT di dalam dalam Al-Qur'an dan terjemahan, (2017):

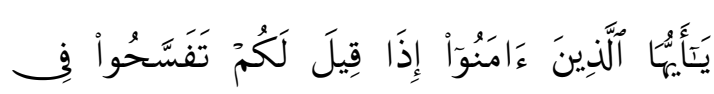

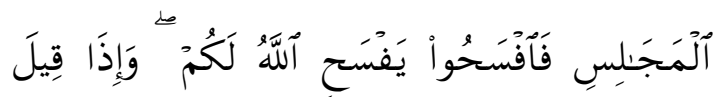

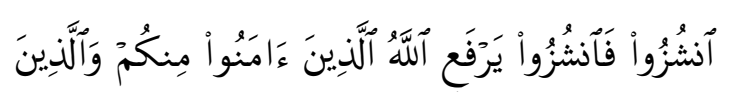

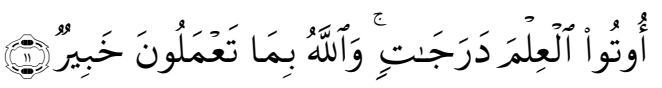

Artinya: "Hai orang-orang beriman apabila dikatakan kepadamu: "berlapang-lapanglah dalam majlis", maka lapangkanlah niscaya Allah akan memberi kelapangan untukmu. Dan apabila dikatakan: "berdirilah kamu", maka berdirilah, niscaya Allah akan meninggikan orang-orang yang beriman di antaramu dan orang-orang yang diberi ilmu pengetahuan beberapa derajat. dan Allah Maha mengetahui apa yang kamu kerjakan." (QS. $\mathrm{Al}$ Mujaadilah ayat 11)

Selain itu, Nabi saw juga pernah bersabda sebagaiman yang diriwayatkan oleh (An-Naisaburi, 2005):

Artinya: "Menuntut ilmu adalah kewajiban bagi setiap Muslim" (HR. Muslim)

\section{Kelemahan Dalam Dokumen Kredit}

Dokumen kredit yang diajukan oleh pemanfaat/masyarakat sudah sesuai dengan ketentuan yang berlaku. Bahkan peneliti melakukan observasi langsung kepada pengurus UED SP melihat dokumen pengajuan kredit dan semuanya sesuai dengan aturan yang berlaku. UED SP Lubuk Muda membatalkan pengajuan kredir kepada pemanfaat jika ada dokumen pengajuan kredit yang tidak lengkap. Namun jika dokumen pengajuan kredit yang diajukan oleh pemanfaat tidak lengkap maka pengurus menginformasikan kepada pemanfaat untuk melengkapinya sesuai dengan batas waktu yang telah ditetapkan. Jika sampai pada batas waktu yang telah ditetapkan pemanfaat tidak juga melengkapi berkas yang kurang tersebut maka pengurus membatalkan pengajuan tersebut secara mutlak.

Tujuan pengurus menginformasikan kepada pemanfaat terkait kelengkapan dokumen tersebut adalah sebagai sebuah upaya transparansi dan keterbukaan informasi kepada publik dan memberikan kemudahan kepada pemanfaat.

Hal ini sesuai dengan syariat Islam bahwa tidak dibenarkan melakukan perbuatan curang karena perbuatan tersebut termasuk dosa. Islam juga mengajarkan bahwa jangan karena kebencian kepada suatu kaum mengakibatkan berlaku tidak adil. Sebagaimana firman Allah SWT dalam Al-Qur'an dan terjemahan, (2017): 


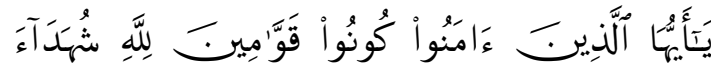

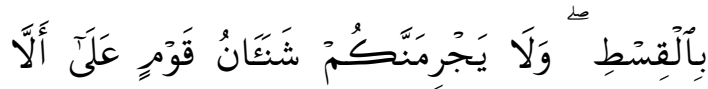

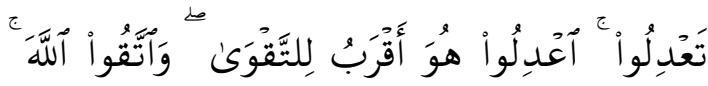

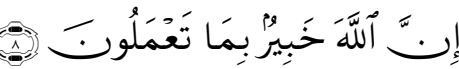

Artinya: "Hai orang-orang yang beriman hendaklah kamu Jadi orang-orang yang selalu menegakkan (kebenaran) karena Allah, menjadi saksi dengan adil. dan janganlah sekali-kali kebencianmu terhadap sesuatu kaum, mendorong kamu untuk Berlaku tidak adil. Berlaku adillah, karena adil itu lebih dekat kepada takwa. dan bertakwalah kepada Allah, Sesungguhnya Allah Maha mengetahui apa yang kamu kerjakan." (QS. Al Maidah ayat 8)

Selain itu, Islam mengajarkan agar mempermudah urusan saudaranya dan tidak boleh mempersulit. Dalam sebuah Hadis dikisahkan bahwa Rasulullah saw pernah berdoa kepada Allah SWT sebagaiman yang diriwayatkan oleh (An-Naisaburi, 2005);

Artinya: "Ya Allah, barangsiapa diberi tanggung jawab untuk menangani urusan umatku, lalu ia persulit mereka maka persulitlah hidupnya. Dan barangsiapa diberi tanggung jawab untuk mengurus umatku lalu ia memudahkan urusan mereka, maka mudahkanlah hidupnya" (HR. Muslim)

\section{Kelemahan Dalam Supervisi Kredit}

Dalam penelitian ini peneliti dapatkan informasi dan dokumen bahwa secara struktur kepengurusan UED SP sudah baik karena melibatkan unsur pemerintahan Desa Lubuk Muda. Namun pengawasan yang selama ini terjadi masih jauh dari yang diamanatkan oleh peraturan yang berlaku. Hal ini terbukti dari total tunggakan yang melebihi angka di atas 1 Milyar Rupiah cukup mengindikasikan penyebab terjadinya kemacetan kredit.

Islam mengajarkan kepada pemeluknya agar bertanggung jawab atas tugas dan beban kerja yang diemban. Allah SWT berfirman dalam Al-Qur'an dan terjemahan, (2017):

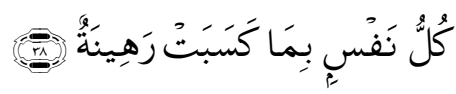

Artinya: "Tiap-tiap diri bertanggung jawab atas apa yang telah diperbuatnya" (QS. Al Mudatstsir ayat 38)

Selain itu, di dalam Islam juga diajarkan bahwa setiap diri adalah pemimpin yang akan ditanya di akhirat kelak. Sebagaimana Hadis Nabi SAW yang diriwayatkan oleh (Al-Bukhari, 2012):

Artinya: "Setiap kamu adalah pemimpin dan setiap pemimpin akan dimintai pertanggungjawaban atas apa yang dipimpin" (HR. Bukhari)

\section{Kelemahan Kebijakan Kredit}

Peraturan tentang pemberian kredit dari UED SP kepada pemanfaat diatur dalam Peraturan Bupati Bengkalis. Secara kontekstual kebijakan tentang pemberian kredit ini sangat membantu masyarakat dalam meningkatkan perekonomian dan mengembangkan usaha mereka. Namun secara substantif sistem yang diterapkan sangat jauh bertentangan dengan syariat Islam. Hal ini dikarenakan sistem pinjaman yang masih menerapkan sistem riba.

Di dalam Islam diajarkan bahwa setiap melakukan muamalah maka mencatat seluruh transaksi yang terjadi. Kebijakan-kebijakan dalam pemberian kredit di dalam Islam mengedepankan aspek kejelasan dan kehalalan baik zat maupun sistem yang digunakan. Sebagaimana firman Allah SWT dalam Al-Qur'an dan terjemahan, (2017): 


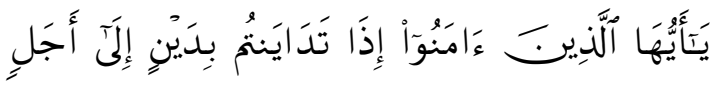

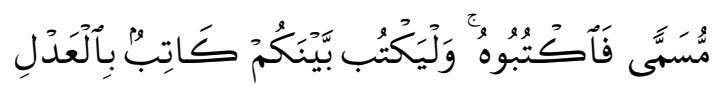

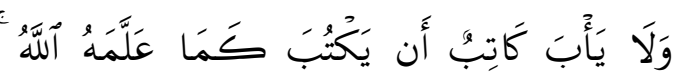

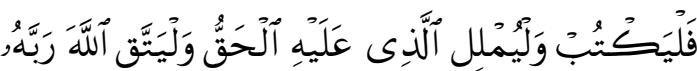

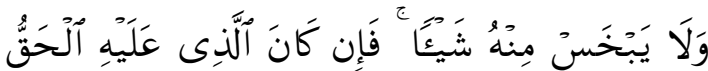

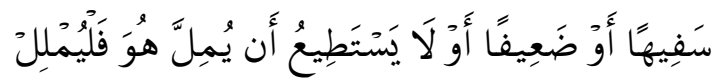

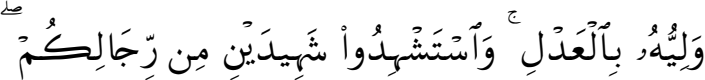

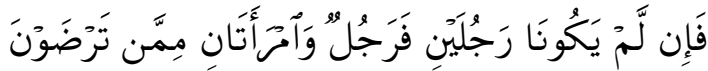

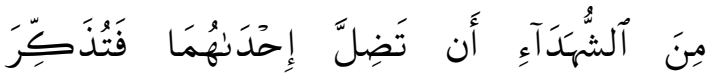

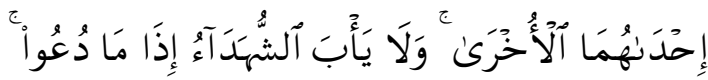

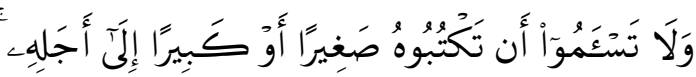

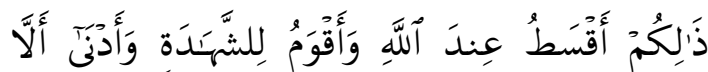

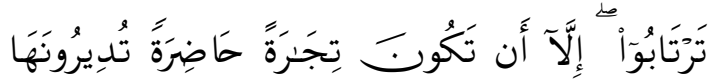

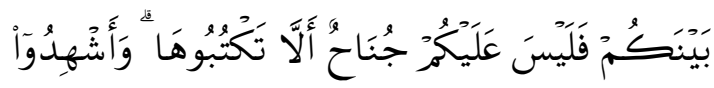

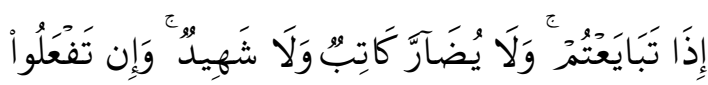

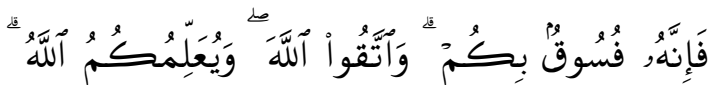

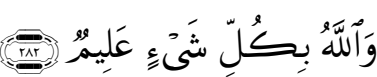

Artinya: "Hai orang-orang yang beriman, apabila kamu bermu'amalah tidak secara tunai untuk waktu yang ditentukan, hendaklah kamu menuliskannya. dan hendaklah seorang penulis di antara kamu menuliskannya dengan benar. dan janganlah penulis enggan menuliskannya sebagaimana Allah mengajarkannya, meka hendaklah ia menulis, dan hendaklah orang yang berhutang itu mengimlakkan (apa yang akan ditulis itu), dan hendaklah ia bertakwa kepada Allah Tuhannya, dan janganlah ia mengurangi sedikitpun daripada hutangnya. jika yang berhutang itu orang yang lemah akalnya atau lemah (keadaannya) atau Dia sendiri tidak mampu mengimlakkan, Maka hendaklah walinya mengimlakkan dengan jujur. dan persaksikanlah dengan dua orang saksi dari orang-orang lelaki (di antaramu). jika tak ada dua oang lelaki, Maka (boleh) seorang lelaki dan dua orang perempuan dari saksi-saksi yang kamu ridhai, supaya jika seorang lupa Maka yang seorang mengingatkannya. janganlah saksi-saksi itu enggan (memberi keterangan) apabila mereka dipanggil; dan janganlah kати јети menulis hutang itu, baik kecil maupun besar sampai batas waktu membayarnya. yang demikian itu, lebih adil di sisi Allah dan lebih menguatkan persaksian dan lebih dekat kepada tidak (menimbulkan) keraguanтu. (Tulislah ти'amalahmu itu), kecuali jika mu'amalah itu perdagangan tunai yang kamu jalankan di antara kamu, Maka tidak ada dosa bagi kamu, (jika) kamu tidak menulisnya. dan persaksikanlah apabila kamu berjual beli; dan janganlah penulis dan saksi saling sulit menyulitkan. jika kamu lakukan (yang demikian), Maka Sesungguhnya hal itu adalah suatu kefasikan pada dirimu. dan bertakwalah kepada Allah; Allah mengajarmu; dan Allah Maha mengetahui segala sesuatu." (QS. Al Baqarah ayat 282)

Padahal di dalam Islam diajarkan bahwa akad ada 2 (dua) yaitu; tabarru' dan tijarah. Tabarru' merupakan akad tolong menolong/social oriented seperti akad al Qardh. Sedangkan tijarah adalah akad yang berorientasi pada keuntungan yang diatur dalam syariat Islam/profit oriented.

Kebijakan pemberian kredit di dalam Islam juga harus menghindari adanya unsur riba. Riba yang dilakukan sesungguhnya tidak akan menambah keberkahan di dalam kehidupan, justru mendatangkan keburukan kepada 
pelakunya. Sebagaimana Hadis Nabi Muhammad saw yang diriwayatkan oleh (Al-Bukhari, 2012):

Artinya: "Dari Abu Hurairah Radhiyallahuanhu, dari Nabi Shallallahu 'alaihi wa sallam, Beliau bersabda, "Jauhilah tujuh (dosa) yang membinasakan!” Mereka (para sahabat) bertanya, "Wahai Rasûlullâh! Apakah itu?" Beliau menjawab, "Syirik kepada Allâh, sihir, membunuh jiwa yang Allâh haramkan kecuali dengan haq, memakan riba, memakan harta anak yatim, berpaling dari perang yang berkecamuk, menuduh zina terhadap wanita-wanita merdeka yang menjaga kehormatan yang beriman dan yang bersih dari zina". (HR. Al-Bukhari)

\section{Kecerobohan Petugas}

Kecerobohan petugas pada sebuah lembaga keuangan baik bank maupun non bank sangat memungkin terjadi. Karena selain dengan jumlah nasabah/pemanfaat yang ramai maka mengakibatkan kesalahan dalam pemberkasan.

Peneliti menemukan bahwa tingkat kecerobohan petugas/pengurus dalam pemberkasan dokumen pemanfaat UED SP sangat minim. Karena pencairan dana kepada pemanfaat tidak dilakukan setiap hari namun sesuai dengan instruksi dari kabupaten. Maka banyak waktu senggang yang bisa dimanfaatkan oleh pengurus untuk menilai dan menyusun dokumen pinjaman pemanfaat.

Islam mengajarkan kehati-hatian dalam berfikir, berucap dan berperilaku kepada manusia. Tidak dibenarkan melakukan sesuatu dengan terburu-buru dan tidak dibenarkan melalaikan sesuatu yang menjadi tanggung jawab baik pribadi maupun tanggung jawab sosial. Allah SWT berfirman dalam Al-Qur'an dan terjemahan, (2017):

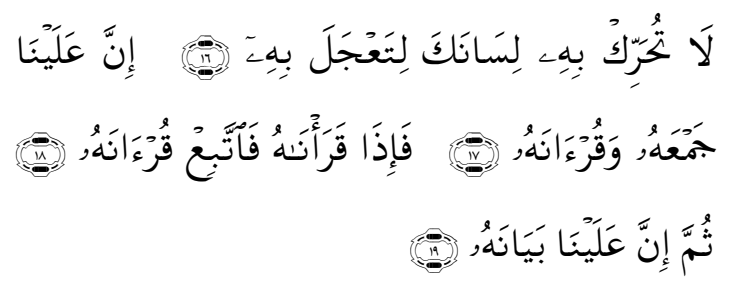

Artinya: "Janganlah kamu gerakkan lidahmu untuk (membaca) Al Quran karena hendak cepat-cepat (menguasai)nya. Sesungguhnya atas tanggungan kamilah mengumpulkannya (di dadamu) dan (membuatmu pandai) membacanya. Apabila Kami telah selesai membacakannya Maka ikutilah bacaannya itu. Kemudian, Sesungguhnya atas tanggungan kamilah penjelasannya." (QS. Al Qiyamah ayat 16-19)

6. Kelemahan dalam Bidang Agunan

Salah satu persyaratan dalam pengajuan dokumen pinjaman kepada nasabah/pemanfaat, UED SP menerapkan sistem agunan. Artinya setiap pemanfaat yang akan melakukan pinjaman maka wajib melampirkan agunan/jaminan yang asli dan diserahkan kepada pengurus UED SP.

Besaran nominal pinjaman tergantung kepada agunan yang diserahkan. Semakin tinggi nilai agunan maka semakin besar pula jumlah pinjaman yang akan diterima, begitu pula sebaliknya.

Islam membenarkan bahwa ketika akan melakukan pinjaman maka menyerahkan jaminan kepada peminjam. Sebagaimana Hadis Nabi SAW yang diriwayatak oleh (At-Tirmidzi, 2008): Artinya: "Kaum muslimin terikat dengan syarat-syarat yang mereka buat, kecuali syarat yang mengharamkan yang halal atau menghalalkan yang haram." (HR. Tirmidzi).

Hal ini juga bertujuan untuk berjaga-jaga jika suatu saat seseorang tersebut tidak sanggup/tidak mampu 
mengembalikan objek pinjaman tersebut, maka agunan tersebut menjadi milik si peminjam. Namun tentu setelah melalui proses dan tahapan yang benar. Sebagaimana yang diatur di dalam akad Al Qardh, Murabahah, Mudharabah, Musyarakah dan lain-lain.

\section{Kelemahan Sumber Daya Manusia}

Sebagaimana yang telah dijelaskan pada indikator sebelumnya bahwa kemampuan analisa pengurus UED SP desa Lubuk Muda masih minim. Ini berarti bahwa perlu adanya pendidkan dalam bentuk seminar, pelatihan dan lain sebagainya dalam upaya memaksimalkan fungsi pengurus di dalam mengelola lembaga keuangan non bank tersebut.

Allah SWT sangat mencintai Muslim yang kuat dibandingkan Muslim yang lemah. Sebagaimana Hadis Nabi SAW yang dikutip oleh (Nawawi, 2012) dalam kitabnya Riyadhus Shalihin:

Artinya: "Mukmin yang kuat itu lebih baik dan lebih dicintai oelh Allah daripada Mukmin yang lemah". (HR. Muslim)

\section{Kelemahan Teknologi}

Dalam pengelolaan sistem pinjaman, UED SP desa Lubuk Muda tidak terlalu banyak menggunakan teknologi. Hanya menggunakan media komputer sebagai rekapan transaksi dan pembuatan laporan keuangan. Selebihnya masih menggunakan sistem manual. Namun di tengah era digital saat ini, sangat dibutuhkan sistem digital yang baik dalam melakukan suatu pekerjaan. Bahkan pengurus sebaiknya menggunakan aplikasi dalam membuat laporan keuangan.

Islam sangat menekankan kepada pemeluknya untuk menuntut ilmu hingga terbentuk sebuah peradaban Islam yang baik. Mustahil Islam bisa berkembang di seluruh pelosok bumi jika tidak dikembangkan melalui ilmu pengetahuan yang baik. Bahkan jika melihat pada fakta sejarah, sangat banyak ilmuan Muslim yang diakui oleh dunia dan keilmuan mereka masih diakui dan dimanfaatkan hingga saat ini.

Allah SWT berfirman dalam dari Al-Qur'an dan terjemahan, (2017):

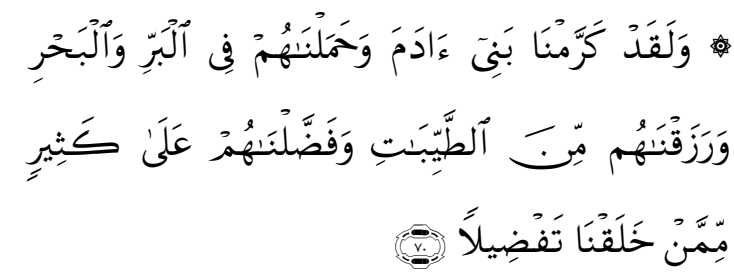

Artinya: "Dan sesungguhnya telah Kami muliakan anak-anak Adam, Kami angkut mereka di daratan dan di lautan, Kami beri mereka rezeki dari yang baik-baik dan Kami lebihkan mereka dengan kelebihan yang sempurna atas kebanyakan makhluk yang telah Kami ciptakan." (QS. Al Israa' ayat 70)

9. Kecurangan Petugas

Salah satu penyebab terjadinya tunggakan yang tinggi pada UED SP desa Lubuk Muda adalah karena kecurangan pengurus. Berdasarkan hasil wawancara peneliti kepada kepala desa Lubuk Muda dan bersama pihak-pihak terkait, bahwa telah terjadi penyelewengan dana dan kebijakan yang dilakukan oleh ketua UED SP desa Lubuk Muda. Maka dilakukan tindakan tegas ketika itu sehingga ketua pengelola UED SP ketika itu diberhentikan dari jabatannya dan diminta untuk mengembalikan sejumlah dana yang telah diselewengkan. Hingga saat ini ketua UED SP yang melakukan kecurangan tersebut masih belum mampu melunasi seluruh dana yang telah diselewengkan.

Islam sangat mengecam perilaku curang dan khianat. Ketidakjujuran di dalam Islam bahkan digolongkan ke dalam golongan orang-orang munafiq dan perbuatan tersebut termasuk perbuatan 
dosa. Di dalam Al-Qur'an dan terjemahan, (2017) Allah berfirman;

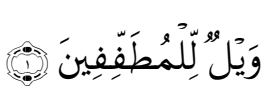

Artinya: "Celakalah bagi orang-orang yang berbuat curang" (QS. Al Muthaffifin ayat 1)

\section{KESIMPULAN}

Berdasarkan pengujian indikator variabel dan data yang didapatkan serta hasil penelitian yang telah dilakukan, maka dapat disimpulkan beberapa hal berikut ini: Penyebab utama terjadinya kemacetan dalam pinjaman UED SP desa Lubuk Muda adalah penyelewengan dana yang dilakukan oleh ketua UED SP dan kelemahan pengurus dalam menganalisa kredit ketika pemanfaat mau melakukan pinjaman di UED SP. Selain kelemahan dalam analisa kredit oleh pengurus, peneliti juga menemukan bahwa minimnya kemampuan pengurus dalam mengoptimalisasikan pemanfaatan teknologi. Serta sistem pemberian kredit pada UED SP desa Lubuk Muda belum sesuai dengan konsep dan prinsip ekonomi Islam, karena UED SP desa Lubuk Muda masih menggunakan sistem riba. Adapun sistem riba yang dimaksud adalah pada saat pemanfaat membayarkan angsuran pinjaman kepada UED SP Pemanfaat membayar pokok + bunga/tambahan yang memang telah disepakati di awal akad pinjaman. Hal ini jelas tidak dibenarkan dalam syariat Islam. Dengan demikian, akad yang digunakan pada UED SP batal secara syariah Islam.

\section{DAFTAR PUSTAKA}

Al-Bukhari, Abu Abdullah Muhammad bin Ismail. 2012. Ensiklopedia Hadits; Terj. Shahih Al-Bukhari. Cet. I. Almahira. Jakarta.

Al-Qur'an dan terjemahan. 2017. Kementrian Agama Republik
Indonesia. Pustaka Al-Kautsar. Jakarta.

An-Naisaburi, Muslim Bin Hajjaj. 2005. Shahih Muslim Cet.I. Daar alMa'rifah Littiba'ah Wannasyri Wattauzi'. Bairut Lebanon.

Antonio, Muhammad Syafi'i. 2001. Bank Syariah dari Teori ke Praktik. Gema Insani Press. Jakarta.

At-Tirmidzi, Muhammad Bin Isa Bin Surah. 2008. Sunan At-Tirmidzi. Cet.II. Maktabah Al-Ma'aarif LinNasyr Wattauzi'. Riyadh.

Bogdan, R., \& Biklen, S. K. 1997. Qualitative research for education. MA: Allyn \& Bacon. Boston.

Budisusila, Antonius. 2009. Rakyat, Pendidikan, dan Ekonomi: Menuju Pendidikan Ekonomi Kerakyatan,: Universitas Sanata Dharma. Yogyakarta

Firdaus, R., Prayugo, P., \& Huda, N. 2020. Pemanfaatan Dana Desa dalam Pembangunan Desa dan Pemberdayaan Masyarakat Desa di Desa Ulu Pulau. Bertuah: Jurnal Syariah dan Ekonomi Islam, 1(1).

Hariyani, Iswi. 2013. Restrukturisasi dan Penghapusan Kredit Macet. Elex Media Komputindo. Jakarta.

Huda, N. 2020. Uji Kelayakan BUMDesa Lubuk Muda. Diakses dari https://www.nurulhuda.id/2020/11/ uji-kelayakan-bumdesa-lubukmuda.html

Kasmir. 2007. Dasar-dasar Perbankan. PT Raja Grafindo Persada. Jakarta.

Kasmir. 2008. Analisis Laporan Keuangan. Raja Grafindo Persada. Jakarta.

Lexy, J. Moleong. 2012. Metodologi Penelitian Kualitatif. PT. Remaja Rosdakarya. Bandung. 
Mahmoeddin, As. 2002. Melacak Kredit Bermasalah. Pustaka Sinar Harapan. Jakarta.

Munawwir, Ahmad Warson. 1997. Al Munawwir: Kamus Arab-Indonesia Pustaka Progressif.

Nawawi, Imam. 2012. Riyadhus Shalihin. Dar al Kitab al Islamiyah. Beirut.

Nuraini, Putri. 2019. Dampak Ekonomi dari Ihtikar dan Siyasah Al-Ighraq dalam Konsep Jual Beli. $A l$ Hikmah: Jurnal Agama dan Ilmu Pengetahuan, 6(1).

Sugiyono. 2008. Metode Penelitian Kuantitatif, Kualitatif dan $R \& D$. Alfabeta. Bandung. 